Department of Pathology and Laboratory Medicine, Lahey Hospital \& Medical Center, Burlington, ${ }^{1}$ and Department of Pathology, Harvard Medical School, Boston, Massachusetts, ${ }^{2}$ USA

\title{
Point of care testing in the diagnosis and monitoring of diabetes mellitus
}

\author{
Ábel György dr. ${ }^{(1,2)}$
}

\begin{abstract}
Summary
In the past half-century, routine central laboratory testing has become increasingly automated and efficient. The majority of clinical chemistry, immunochemistry and hematology testing is performed using high throughput instrumentation, with sophisticated automation. Point of care testing offers considerable advantages over central laboratory testing such as fast and simple specimen handling, and simpler sample requirement (no additives and mostly blood from finger stick, or urine). The advantage of short turnaround time is particularly important in the inpatient setting for blood glucose monitoring to achieve tight glycaemic control. HbA 1 screening of inpatients, either with a central laboratory method or by means of point of care testing identifies patients previously not diagnosed with diabetes and enables enrolling of these patients in a diabetes treatment program. In the outpatient setting, point of care glucose and $\mathrm{HbA}_{1 c}$ monitoring allow adjustment of therapy without the need of a second appointment in the doctor's office. In recent years, technology enabled patients to use point of care devices at home to assure tighter glucose control. However, point of care testing also has a downside: testing is more expensive than central laboratory testing, the accuracy and reproducibility of many point of care systems are no match to the analytical performance of the central laboratory tests, and performing the assays at home, by the patient's bedside, or in the office requires some skill. In addition, the accuracy of point of care testing in critically ill patients has been questioned recently, and the analytical performance of several commercially available point of care testing systems for $\mathrm{HbA}_{1 c}$ has been found unacceptable. This article succinctly reviews the clinical utility of point of care blood glucose and $\mathrm{HbA}_{1 c}$ testing in the diagnosis and monitoring of patients with type 2 diabetes mellitus, and discusses the caveats and limitations of point of care glucose and $H b A_{1 c}$ testing. Key words: diabetes mellitus, point of care testing, glucose monitoring, haemoglobin $A_{1 c}$
\end{abstract}

\section{A betegágy melletti vizsgálatok szerepe a diabetes mellitus diagnosztikäjäban és nyomon követésében}

Összefoglalás: Az elmúlt ötven évben a rutin laboratóriumokban egyre elterjedtebbé vált az automatizálás, és a vizsgálatok hatékonysága jelentösen megnövekedett. A klinikai kémiai, immunkémiai és hematológiai vizsgálatok túlnyomó többségét automatizált, nagy kapacitású müszerekkel végzik. A betegágy melletti, illetve beteg-közeli laboratóriumi vizsgálatok elönye a központi laboratóriumi vizsgálatokkal szemben a gyors és egyszerü mintavétel és a kis volumenü mintaigény (kapilláris vér ujjbegyböl adalékanyagok nélkül, vagy vizelet). A beteg-közeli vizsgálatok nagyon rövid idöt igényelnek, ami különösen fontos a kórházi fekvöbeteg-ellátásban, ahol a szoros vércukor-ellenörzés és szinten tartás kiemelt fontosságú. A fekvöbetegek szürése beteg-közeli vagy központi laboratóriumi HbA, akik eddig nem tudtak a diabetesükröl és akik a betegségük felfedezése után diabetest kezelö programba irányithatók. A

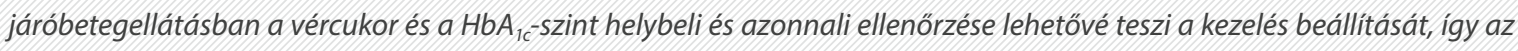
orvos ismételt, néhány napon belüli felkeresése szükségtelenné válik. Az utóbbi évek technológiai fejlödése a betegek vércukor-önellenörzését is lehetövé tette, ami még precizebb glukózkontrollt biztosit. A beteg-közeli vizsgálatoknál azonban néhány komoly hátránnyal is számolnunk kell: ezek a tesztek jóval drágábbak, mint a központi laboratóriumi vizsgálatok, és a vizsgálatok pontossága és reprodukálhatósága sokszor nem éri el a központi laboratóriumi tesztek minöségét. Továbbá a beteg-közeli vizsgálatok elvégzése a beteg otthonában vagy az orvosi rendelöben minden egyszerüsége ellenére bizonyos ismeretet és tapasztalatot igényel. Mindezen túlmenöen, a betegágy mellettivércukor-ellenörzés pontosságát az intenziv betegellátásban megkérdöjelezték. Több, kereskedelmi forgalomban levö beteg-közeli HbA'c-szisztéma pontossá- 
ga és reprodukálhatósága elfogadhatatlan. Ez az összefoglaló cikk röviden áttekinti a beteg-közeli vércukor-és HbA 1 -vizsgálatok használatát és felhivja a figyelmet ezen tesztek analitikai és gyakorlati korlátaira.

Kulcsszavak: diabetes mellitus, betegágy melletti tesztelés, glukózellenörzés, hemoglobin $A_{1 c}$

DIABETOLOGIA HUNGARICA 25 (№3) 179-183. 2017. április DOI: $10.24121 / \mathrm{dh} .2017 .13$

Abbreviations

DM: diabetes mellitus; $\mathbf{H b A}_{1 c}$ : haemoglobin $\mathrm{A}_{1 c}$; HPLC: high performance liquid chromatography; POCT: point of care testing

$\mathrm{P}$ oint of care testing (POCT) has been commonly used for urinalysis, blood glucose testing and monitoring, blood gas and electrolyte testing, coagulation, blood chemistries including enzymes and lipids, drugs of abuse, pregnancy testing, infectious disease testing, cardiac markers, haemoglobin, and hematocrit. POCT is resource intensive in the hospital setting and typically carries higher cost per test than central laboratory testing. ${ }^{1}$ For example, the cost of an $\mathrm{HbA}_{1 \mathrm{c}}$ assay by high performance liquid chromatography (HPLC) in the central laboratory is less than US\$2 (about HUF 600), whereas the POCT immunoassay version can costs as much as US\$10 (HUF 3000). When used for the right reasons, point of care testing can contribute to shorter patient stay in the emergency department or hospital. It is especially true for point of care infectious disease (e.g., influenza) and cardiac marker (e.g., troponin-I) testing. Judiciously used POCT may also contribute to decreased admission rate, lower mortality and overall lower health care costs. Assuring POCT quality is resource intensive and as healthcare budgets get tighter and staffing shortages become more common, the advantages of POCT must be weighed against available resources to determine best testing strategies. ${ }^{2}$ In general, POCT should not replace centralized medical laboratory testing, and should be used only in cases where clear benefits to patient care have been demonstrated. ${ }^{3}$ Detailed and accurate health economics studies are needed to show whether the point of care testing approach is cost-effective.

\section{Point of care glucose monitoring}

With regard to glucose monitoring, inpatient POCT glucose has become a standard procedure in Europe as well as in the United States, with the purpose of assuring tight glycaemic control: the clinical practice of controlling blood glucose levels down to the "normal" 4.4-6.1 mmol/L range of a healthy adult, aiming to avoid any potential deleterious effects of hyperglycaemia. For patients who are on an insulin drip, every minute matters and there is no time to draw blood, send it to the laboratory, and wait for the result, which can take as long as an hour, may be more if the laboratory is momentarily handling high volumes and run to capacity. The pre-analytic phase, (transportation to the laboratory, accessioning, and processing), as well as the post-analytic phase (verifying and reporting the results), and the final phase (sending the result to the health care provider, who may or may not check the results streaming in from the laboratory immediately) time-consuming. ${ }^{4}$

The possible inaccuracies of POCT in the hospital inpatient setting are well compensated by speed. The important clinical issue is to get an immediate „good enough" result rather than an exact, accurate, but delayed result. That said, the imprecision and occasionally erratic results of POCT glucose have been brought into focus by regulatory agencies in the United States, where the use of fingerstick-based POCT for blood glucose monitoring in critically ill patients has been practically banned. The basis of the ban is that the U.S. Food and Drug Administration has not approved any POCT glucose monitoring system for use in this patient population and there is a concern that POCT in this pateint population may be highly inaccurate ${ }^{5,6}$ An extensive debate ensued among clinical diabetes experts, laboratory professionals, representatives of the in vitro diagnostic industry, and the regulatory agencies. ${ }^{7}$ Key opinion leaders concluded that the ban may actually put 
this very vulnerable patient population in jeopardy by practically eliminating tight glycaemic control in those who probably the most need it. ${ }^{8}$ Indeed, measuring glucose from fingertips has several issues, most importantly the mixing of blood with interstitial fluid, rendering the measurements less accurate than in venous or arterial blood. ${ }^{9}$ This inaccuracy is compounded in most critically ill patients (eminently those receiving intensive therapy, on ventilator or are in post-operative care, or in emergency room setting following a major cardiovascular event, accident, or asphyxiation), with the common denominator that essentially all of them suffer, acutely or chronically, from impaired peripheral circulation. Currently, no near-patient glucose assay manufacturer has approval from the FDA for point of care blood glucose monitoring using fingertip blood in this patient population, but the practice is still continuing in many hospitals in spite of the potential citation for violating the regulatory rules.

Part of the issue is the definition of „critically ill" patients, which the regulatory agencies did not want to do, leaving this difficult judgement to the hospitals. All patients who are treated in intensive care units - it could be a simple, practical definition of „critically ill” patients, but this definition is somewhat narrow and certainly does not encompass all critically ill patients. Critically ill patients represent approximately a third of the 6 to 8 thousand point of care glucose tests performed in a mid-size hospital monthly. This volume cannot be eliminated overnight without a very negative effect on the care of these patients. The delay with receiving test results can be deleterous, and the need for phlebotomy or blood sampling from existing intravenous lines (not a good practice) can lead to iatrogenic anemia, and also disliked by both patients and hospital personnel. Laboratory professionals are still trying to find a solution for this ongoing controversy. ${ }^{10,11}$

In addition to the issues with the tight glycaemic control of critically ill patients and the development of best practices for their blood glucose testing, glucose monitoring of the general inpatient population is also under review. It has been known that more than one-third of hospitalized patients have hyperglycaemia. Despite existing evidence that improving glycaemic control leads to better outcomes, achieving recognized targets remains a challenge. According to a recent study, a well-designed computerized insulin order set and titration algorithm improved overall inpatient glycaemic control. ${ }^{12}$

Point of care glucose testing is no longer performed only in the settings of the hospital and the physician's office. Patients have many options to own portable POCT glucose monitoring systems at home. The use of these sytems contributes to a much better glycaemic control in the outpatient setting when used by educated and compliant patients. Fortunately, most of these systems are devoid of old interferences (e.g., maltose interference). Bluetooth and wireless communications enable collection of the numbers not only on the instruments themselves, but the data are easily transferable onto mobile phones and can be shared with the patient's physician or a nurse practitioner. It is expected that point of care devices will become commonplace not only for glucose, but other chemistry analytes, including $\mathrm{HbA}_{1 \mathrm{c}}$. One of the proposed new point of care assays is glycated albumin, that would serve as an intermediary biomarker between POCT glucose and $\mathrm{HbA}_{1 \mathrm{c}}$ for self monitoring, eliminating the need of multiple daily glucose testing in well-controlled DM, allowing, let's say weekly testing. Since the half-life of the albumin molecule is about 17 days, the status of glycated albumin could provide an assessment of glycaemic control over the preceding 2-3 weeks, rather than a marker of average glycaemia in the preceding 2-3 month, $\mathrm{HbA}_{1 \mathrm{c}}$. POCT with this newer marker is still under development.

\section{Point of care $\mathrm{HbA}_{1 c}$ testing}

$\mathrm{HbA}_{1 \mathrm{c}}$ has become a critically important test, especially since the marker gained acceptance as a key diagnostic modality in DM. ${ }^{12}$ HPLC-based assays have been widely used in the hospital and reference laboratory settings. The cost of this test is low and it is very accurate, also allowing the identification of any interference by the presence of variant haemoglobins. In addition to HPLC, chemical and immunochemical assays have also been developed for $\mathrm{HbA}_{1 \mathrm{c}}$ measurement and the more recent versions of these assays are not affected by 
the haemoglobin variant interference. ${ }^{13,14} \mathrm{~A}$ review of the recent literature is strongly recommended before purchasing a point of care $\mathrm{HbA}_{1 \mathrm{c}}$ analyzer, because the quality and analytical performance of these systems greatly varies. ${ }^{15,16,17}$ As of today, there are only a few acceptable POCT $\mathrm{HbA}_{1 \mathrm{c}}$ analyzers are on the market. ${ }^{18,19,20,21}$ In addition to careful system selection, the selection of appropriate controls and calibrators is also of critical importance: the lack of international harmonization may lead to misleading conclusions regarding the cut-off levels of $\mathrm{HbA}_{1 \mathrm{c}}$ for the diagnisis of $\mathrm{DM}^{22}$ The U.S. National Glycohemoglobin Standardization Program (NGSP) now has an international reach and the organization plays an important role in the international standardization of $\mathrm{HbA}_{1 \mathrm{c}}$ testing, and harmonization of the results.

While the laboratory standardization of $\mathrm{HbA}_{1 \mathrm{c}}$ testing is spearheaded by NGSP, in the United States the standards of medical care for diabetes are set and regularly updated by the American Diabetes Association (ADA). The most recent Standards were published in $2016 .{ }^{23}$ The standards reviewed the diagnostic tests for DM (fasting plasma glucose, 2-h plasma glucose after a 75 -g oral glucose tolerance test, and $\mathrm{HbA}_{1 \mathrm{c}}$ criteria) and made it clear that no one test is preferred over another for diagnosis. ${ }^{24}$ Also, the 2016 standards recommend that all adults beginning at age 45 years, regardless of weight should be screened for diabetes. Testing is also re-commended for asymptomatic adults of any age who are overweight or obese and who have one or more additional risk factors for diabetes. In addition to the ADA Standards, separate hospital guidelines have been developed by a U.S. non-profit organization and accrediting agency called the Joint Commission, in collaboration with ADA, for inpatient diabetes screening and treatment. ${ }^{25}$

In Hungary, a tremendous work has been done by the clinical and scientific leadership of the Hungarian Diabetes Association over the past decades. A risk-stratified screening system for DM has been developed, ${ }^{26}$ which was accompanied by an effort to also screen for prediabetes in order to catch the developing disease in an early stage and with appropriate intervention to reverse or at least slow down the disease process. ${ }^{27}$ The Hungarian National Diabetes Program, de- veloped in 2011, serves as a very detailed guideline to the diagnosis, treatment, and management of adult DM. ${ }^{28}$ The guideline reflects state-ofart in its scientific and clinical content and one would hope that the resources critically needed for a full implementation and continuation of the program will be secured. Recent surveys indicate an increased prevalence of self-reporting of $\mathrm{DM}^{29}$ and the cost-effectiveness of the screening program has been well established. ${ }^{30}$ With early diagnosis of prediabetes, lifestyle and diet changes can be made that prevent the development of DM in most patients. Early treatment of both prediabetes and DM can save not only lives, but also a very large amount of money to the health care system. The costs of early treatment and continuing care in a diabetes management program are relatively small compared to the huge cost burden of the complications of DM such as cardiovascular disease, blindness, kidney disease, peripheral neuropathy, foot pain and ulcers, etc. The laboratory diagnostic modalities discussed in this review article can significantly contribute to the success of the program. 


\section{References}

1. Abel G: Current status and future prospects of point-of-care testing around the globe. Expert Rev Mol Diagn 2015; 15(7): 853-855. doi:10.1586/14737159.2015.1060126

2. McPartlin DA, O'Kennedy RJ: Point-of-care diagnostics, a major opportunity for change in traditional diagnostic approaches: potential and limitations. Expert Rev Mol Diagn 2014; 14(8): 979-998. doi:10.1586/14737159.2014.960516

3. Nichols JH: Quality in point-of-care testing. Expert Rev Mol Diagn 2003; 3(5): 563-572. doi:10.1586/14737159.3.5.563

4. Schimke I: Quality and timeliness in medical laboratory testing. Anal Bioanal Chem 2009; 393(5): 1499-1504. doi:10.1007/s00216-008-2349-5

5. Lacara T, Domagtoy C, Lickliter D, Quatrocchi K, Snipes L, Kuszaj J, et al.: Laboratory glucose analysis in critically ill patients. Am I Crit Care 2007; 16(4): $336-346$.

6. Wiener RS, Wiener DC, Larson, RJ: benefits and risks of tight glucose control in critically ill adults. JAMA 2008; 300(8):933-944. doi:10.1001/jama.300.8.933

7. Clarke W, DuBois JA: Potential conflict between analytical performance standards and clinical safety and efficacy of whole blood glucose measurement devices. Point of Care 2014; 13(3): 107-111. doi:10.1097/POC.0000000000000024

8. Klonoff DC, Vigersky RA, Nichols JH, Rice, MJ: Timely hospital glucose measurement: Here today, gone tomorrow? Mayo Clin Proc 2014; 89(10): 1331-1335. doi:10.1016/j.mayocp.2014.08.005

9. Klonoff $D C$ : Point-of-care blood glucose meter accuracy in the hospital setting Diabetes Spectr. 2014; 27(3): 174-179. doi:10.2337/diaspect.27.3.174

10. Khan Al: Using glucose meters in hospital environments; some challenges and resolutions for point-of-care testing. Editorial. Point of Care (2014); 13(3): $97-100$

11. Narla SN, Jones M, Hermayer KL, Zhu Y: Critical care glucose point-of-care testing. Adv Clin Chem. 2016; 76: 97-121. doi:10.1016/bs.acc.2016.05.002

12. Sinha GN, Seley JJ, Gerber LM, Tang C, Brillon D: Decreased rates of hypoglycemia following implementation of a comprehensive computerized insulin order set and titration algorithm in the inpatient setting. Hosp Pract 2016; 44(5): 260-265. doi:10.1080/21548331.2016.1250603

13. Solvik UO, Roraas T, Christensen NG, Sandberg S: Diagnosing diabetes mellitus: performance of hemoglobin ATC point-of-care instruments in general practice offices. Clin Chem 2013; 59(12): 1790-1801. doi:10.1373/dinchem.2013.210781

14. Schnell 0 , Crocker JB, Weng J: Impact of $\mathrm{HbA}_{1}$ testing at point of care on diabetes management. Review. J Diabetes Sci Technol 2016 Nov 27. pii: 1932296816678263. [Epub ahead of print] doi:10.1177/1932296816678263

15. Lenters-Westra E, Slingerland RJ: Six of eight hemoglobin ATc point-ofcare instruments do not meet the general accepted analytical performance criteria. Clin Chem 2010; 56(1): 44-52. doi:10.1373/clinchem.2009.130641

16. Bruns DE, Boyd JC: Few point-of-care hemoglobin ATc assay methods meet clinical needs. Clin Chem 2010; 56(1): 4-6. doi:10.1373/clinchem.2009.139865

17. Irvin B, Knaebel J, Simmons D: Assessing the performance of pointof-care hemoglobin A1c systems. Clin Chem 2010; 56(8):1359-1360. doi:10.1373/clinchem.2010.147736

18. Lenters-Westra E, Slingerland RJ: Three of 7 hemoglobin Alc point-of-care instruments do not meet generally accepted analytical performance criteria. Clin Chem 2014; 60(8): 1062-1072. doi:10.1373/dinchem.2014.224311

19. Torregrosa ME, Molina J, Argente CR, Ena J: Accuracy of three hemoglobin Alc point-of-care systems for glucose monitoring in patients with diabetes mellitus. Endocrinol Nutr 2015; 62(10): 478-484. doi:10.1016/j.endonu.2015.07.007
20. Paknikar S, Sarmah R, Sivaganeshan L, Welke A, Rizzo A, Larson K, et al:. Long-term performance of point-of-care Hemoglobin Alc Assays. J Diabetes Sci Technol 2016; 10(6): 1308-1315. doi:10.1177/1932296816645362

21. Al-Ansary $\mathrm{L}$, Farmer $\mathrm{A}$, Hirst J, Roberts $\mathrm{N}$, Glasziou P, Perera $\mathrm{R}$, et al.: Pointof-care testing for $\mathrm{Hb} \mathrm{AlC}$ in the management of diabetes: a systematic review and metaanalysis. Review. Clin Chem 2011; 57(4): 568-576. doi:10.1373/clinchem.2010.157586

22. Umemoto M, Raneva V, Tominaga M, Kuwa $K$, Ábel G, Takei I, et al:: Relationship between NGSP and JDS HbA $A_{1 c}$ numbers. Diabetol Int 2015; 6(1): 77-81. doi:10.1007/s13340-014-0173-z

23. Chamberlain JJ, Rhinehart AS, Shaefer CF Jr, Neuman A: Diagnosis and management of diabetes: Synopsis of the 2016 American Diabetes Association Standards of Medical Care in Diabetes. Ann Intern Med 2016; 164(8): 542-552. doi:10.7326/M15-3016

24. American Diabetes Association Standards of Medical Care in Diabetes - 2016. Diabetes Care 2016; 39(Suppl 1): S51-S112.

25. Arnold P, Scheurer D, Dake AW, Hedgpeth A, Hutto A, Colquitt C, et al:: Hospital guidelines for diabetes management and the Joint CommissionAmerican Diabetes Association inpatient diabetes certification. Am J Med Sci 2016; 351(4):333-341. doi:10.1016/j.amjms.2015.11.024

26. Winkler G, Hidvégi T, Vándorfi G, Jermendy G: [Risk-stratified screening for diabetes in adults: results of the first investigation in Hungary]. Hungarian. Orv Hetil 2010; 151(17): 691-696. doi:10.1556/0H.2010.28819

27. Jermendy G, Hidvégi T, Vándorfi G, Winkler G: IScreening for type 2 diabetes and prediabetes - methodological concerns and feasibility in Hungary]. Review. Hungarian. Orv Hetil 2010; 151(17): 683-90. doi:10.1556/0H.2010.28818

28. Jermendy G, Barkai L, Blatniczky L, Halmos T, HidvégiT, Kaló Z, et al: Nemzeti Diabetesprogram 2011. Diabetol Hung (2011); 19(3): S1-39.

29. Domján BA, Ferencz V, Tänczer T, Szili-Janicsek Z, Barkai L, Hidvégi T, et al.: Large increase in the prevalence of self-reported diabetes based on a nationally representative survey in Hungary. Prim Care Diabetes 2016; Sep 23. pii: S1751-9918. doi:10.1016/j.pcd.2016.09.001

30. Nagy B, Zsólyom A, Nagyjánosi L, Merész G, Steiner $T$, Papp E, et al.: Cost-effectiveness of a risk-based secondary screening programme of type 2 diabetes. Diabetes Metab Res Rev 2016; 32(7): 710-729. doi:10.1002/dmrr.2791

\section{Corresponding author:}

Dr. Ábel György

E-mail: gabel@hms.harvard.edu 